\title{
C U M U L A T I V E I N D E X
}

\author{
Journal of INTERAMERICAN STUDIES \\ and WORLD AFFAIRS
}

Volume 1 - Volume 20

$1959-1978$

Compiled by Gerry Machovec

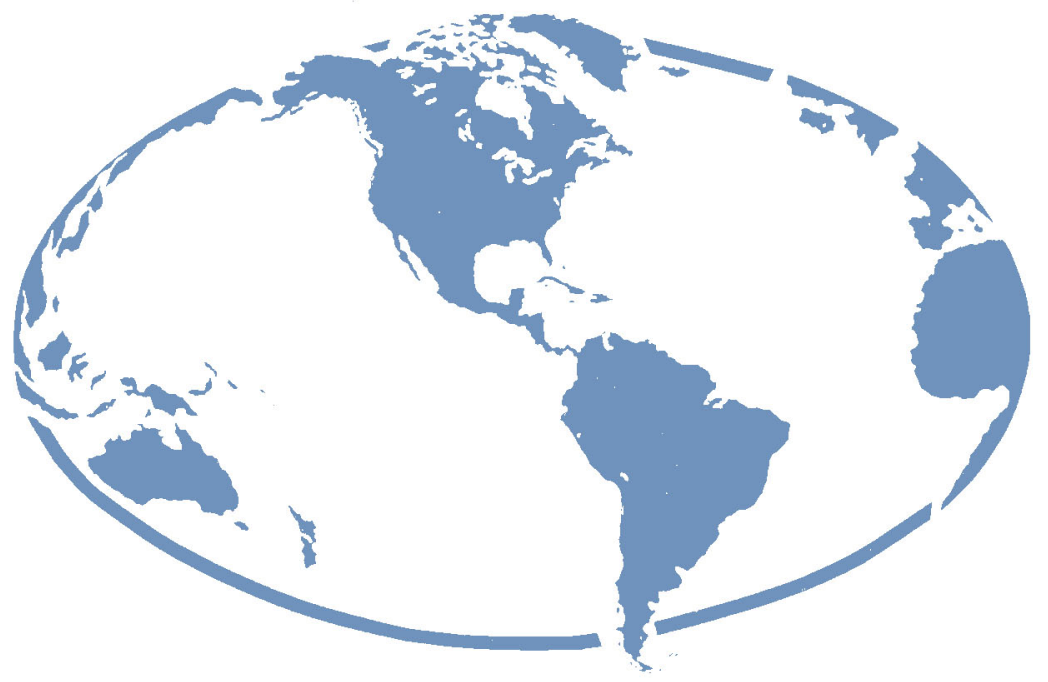

SAGE Publications / Beverly Hills / London 


\section{Journal of INTERAMERICAN STUDIES and WORLD AFFAIRS}

\section{A Publication of the Center for Advanced \\ International Studies, \\ The University of Miami}

\section{EDITORIAL STAFF:}

John P. Harrison -Editor

Jan Peter Wogart -- Associate Editor

Gerry Machovec-Editorial Assistant

\section{BOARD OF EDITORS:}

Orlando Albornoz, Universidad Central de Venezuela

D. A. Brading, Cambridge University

Tom E. Davis, Cornell University

Malcolm Deas, St. Antony's College, Oxford, England

Mose Harvey, University of Miami

Isaac Kerstenetzky, Instituto Brasileiro de Geografia e Estatistica,

Brazil

Abraham Lowenthal, Woodrow Wilson International Center for Scholars Carmelo Mesa-Lago, University of Pittsburgh

James J. Parsons, University of California, Berkeley

Clark Reynolds, Stanford University

Richard Schaedel, University of Texas, Austin

Hanns-Albert Steger, Universität Erlangen-Nürnberg, Germany

Alfred Stepan, Yale University

Ione Wright, University of Miami, Emeritus

The editors and publisher wish to acknowledge with gratitude the assistance and encouragement of the Center for Advanced International Studies, University of Miami, in providing ancillary services and support for this journal.

() 1979 by Sage Publications, Inc. 


\section{Journal of INTERAMERICAN STUDIES and WORLD AFFAIRS CUMULATIVE INDEX \\ Volume 1 - Volume 20 $1959-1978$ \\ CONTENTS}

Introduction 5

Chronological Index 11

Subject Index $\quad 47$

Countries $\quad 55$

Author Index $\quad 57$ 